\title{
Immigration in the populist crucible: comparing Brexit and Trump
}

\author{
Christian Joppke
}

Correspondence: joppke@sozunibe.ch University of Bern, Bern, Switzerland

\begin{abstract}
The successful Brexit referendum and the election of Trump in 2016 mark the breakthrough of populism in the West. Opposition to immigration has been central to both events. However, it has been central in different ways. This paper maps these differences and the implications of both populisms for a liberal immigration policy. Driven by hostility to free mobility within the $\mathrm{EU}$, the ironic consequence of Brexit will be an immigration policy that is less discriminatory than previously, in the sense that favoritism for other Europeans is now ruled out. By contrast, Trump's immigration policy is openly and brazenly discriminatory. In particular, its Muslim Ban breaches the "anti-populist norm" (Freeman 1995) and thus the essence of a liberal immigration policy.

Keywords: Immigration policy, Populism, Liberalism, Britain, United States
\end{abstract}

\section{Introduction}

The 2016 Brexit referendum and the US election victory of Donald Trump will be remembered as the breakthrough of populism in the West. Perhaps not by accident, the two societies that had been the champions of neoliberalism in the early 1980s, and of the globalization that started at the end of the decade, succumbed to a nationalist populism that prescribes "closure" against "openness", the "new political divide" of our time. $^{1}$

It is a truism that opposition to immigration has been central to both Brexit and the rise of Trump, much as it has been central to the entire phenomenon of nationalist populism whose crest the two events represent. But immigration has been central to them in different ways. To explore these differences is the purpose of this paper. How has immigration been processed in both instances of populism, and what are the implications of both populisms for a liberal immigration policy?

As I shall argue, Brexit, while thriving on a long-held British animus against Europe, has been fundamentally a backlash against the first ever open and expansive immigration policy in modern Britain, which had been ventured by New Labour under Tony Blair. Crucially, New Labour's immigration policy was expansive throughout the skill

\footnotetext{
1"The New Political Divide”, The Economist, 30 July 2016, p.7.
}

( ) The Author(s). 2020 Open Access This article is licensed under a Creative Commons Attribution 4.0 International License, which permits use, sharing, adaptation, distribution and reproduction in any medium or format, as long as you give appropriate credit to the original author(s) and the source, provide a link to the Creative Commons licence, and indicate if changes were made. The images or other third party material in this article are included in the article's Creative Commons licence, unless indicated otherwise in a credit line to the material. If material is not included in the article's Creative Commons licence and your intended use is not permitted by statutory regulation or exceeds the permitted use, you will need to obtain permission directly from the copyright holder. To view a copy of this licence, visit http://creativecommons.org/licenses/by/4.0/. 
ladder, including low-skilled immigration, which-more than high-skilled immigration-had always been the fulcrum of populist aversion, not only in Britain. ${ }^{2}$ For New Labour's openness to the low-skilled stands the fateful non-moratorium on Eastern migration, especially from Poland, after the 2004 EU Enlargement. Because "mass EU immigration" figured centrally in the phenomenal rise of the UK Independence Party (UKIP), ${ }^{3}$ no singular factor has been more decisive for setting Brexit into motion. However, as much as Brexit may be looked at as populist reaction to a too expansive immigration policy, in terms of accepting high numbers that were far above the limit of what was commonly held acceptable, it does not change the quality of a liberal immigration policy. Post-Brexit, the UK will embrace the typical combination of courting high-skilled while restricting low-skilled immigration, standard throughout the OECD world, only without any special deal for Europeans (see MAC 2018, 2020). In the sly rhetoric of some Brexit advocates, like Michael Gove, a post-Brexit immigration policy will even be less "racist" than pre-Brexit, because it will be more open for nonEuropeans: "(O)utside the European Union we can have a truly colour-blind migration policy that, if the British people want to, treats people from the Bahamas in the same way as we treat people from Bulgaria." ${ }^{4}$

By contrast, the rise of Trump, to move to the second populist shock of 2016, goes along with a threat to the fundaments of a liberal immigration policy. This is because the "anti-populist norm", according to a classic paper by Gary Freeman (1995) the core of a liberal immigration policy, has been breached; this norm stipulates the taboo for elites to address the ethno-racial composition of migrant intakes. Already candidate Trump had made disparaging remarks about Mexican immigrants as "bad hombres" and "criminals, drug-dealers, rapists". Once in office, the most far-reaching and legally consequential case of breaching the anti-populist norm has been his "Muslim Ban" (later rebranded "Travel Ban"), which prohibits the entry of citizens from several Muslim-majority countries into the US. A mellowed version of it has been held constitutional by the US Supreme Court in June 2018. Two constitutional principles come to a head here: the traditional "plenary power" of the presidency over foreign affairs and immigration, and the antidiscrimination norm that, since the civil rights era, has put limits on the federal government's immigration powers and that is the legal essence of a liberal immigration policy. The Muslim ban is a test case of how deeply the new nationalist populism can cut into ethnically and racially non-discriminatory immigration policies, which have become the standard since the 1960s.

To home in on Brexit and Trump is not to deny that radical right parties, the spearhead of populism in the West, had sought to influence immigration policies for several decades already. This is documented in a literature that is too vast to be surveyed here. Importantly, this literature is inconclusive about the actual impact of the radical right on immigration policy. Cas Mudde found radical right parties "dogs that bark loud, but hardly ever bite" (2013, p. 14). Writing earlier in the millennium, Tim Bale (2003)

\footnotetext{
${ }^{2}$ According to a Pew Research survey of 2019, even among those who want less overall immigration, half or more support more skilled immigration. This pattern can be found in the major countries of Western Europe (Germany, France, UK, and others), and in the classic immigration countries (US, Canada, Australia) (see Lind 2020, p. 78, fn.23).

${ }^{3}$ UKIP leader Nigel Farage, quoted in Ford and Goodwin (2014, p. 91).

4“Michael Gove: Brexit's not made UK less welcoming to immigrants", BBC News (https://www.bbc.com/ news/uk-politics-43821484).
} 
pointed out that mainstream center-right parties had taken restrictive positions on immigration long before radical right parties were around. Earlier still, Rogers Brubaker (1995, p. 908), in a rebuttal of Freeman's (1995) "anti-populist norm", described European immigration policy as "chronically populist", even before populism existed as distinct parties or movements. A study of the manifestos of 68 political parties in 17 European countries between 1980 and 2014 found that mainstream parties, whether right or left, have increasingly "accommodated" radical right demands, particularly on their favored "liberal-authoritarian" issues (which includes immigration, minorities, and law and order) (Wagner and Meyer 2017). On the other hand, an analysis of more than fifty years of mainstream party manifestos in 12 West European countries, between the early 1960s and 2013, found that "(o)n dimensions of salience, substance, and stance, (there is) little evidence that (anti-immigrant parties)", which after all are everywhere minority or even niche parties, "dictate or even influence how centrist parties address the topic (of immigration)" (Dancygier and Margalit 2019, p. 33).

The jury about the influence of the populist right is out. The significance of Brexit and Trump consists of the fact that a minority force has suddenly acquired majority status, thus potentially shaping the law of the land, including that on immigration. This justifies the focus on the "double shock" of 2016. In addition, an in-depth account of the mutual implication of populism and immigration policy in just two cases allows detecting nuances and ironies that are often lost in the large- $\mathrm{N}$ designs that predominate in the literature.

\section{Brexit}

In a famous commentary on British immigration policy, Gary Freeman (1994) had called Britain "the deviant case". While all other Western democracies were plagued by a "gap" between expansionist immigration policy outcomes and restriction-minded mass publics, the case of Britain proved, on the opposite, that "it is possible to limit unwanted immigration" (ibid. 297). Freeman plausibly referred this fact to "the work of a responsible political elite" that, in a context of strong and responsive parliamentary institutions, took public concerns about "non-European immigration" serious from the start (ibid. 300). Two decades later, two sociologists found that "migration and the European Union's foundational commitment to the free movement of persons" was "central to the causes and consequences of Brexit" (Favell and Barbulescu 2018, p. 118). This constitutes a double puzzle: not only does Britain no longer seem to be a "deviant case"; in addition, the public anti-immigration animus has moved from non-European to European migrants.

The first thing to notice is that Britain had never really arrived in Europe. Churchill's "(w)ith Europe, but not of it" remains the most positive thing one could say about their relationship (quoted in Evans and Menon 2017, p. 1). All major studies on the "Europeanization" of national identities noticed the British exception (Fligstein 2008, Chapter 6; Risse 2010, p. 81). A recent analysis of the Brexit vote even found the low level of British identification with Europe a "key contributor" to its outcome (Carl et al. 2019, p. 282). In light of this, UKIP leader Nigel Farage's polemical neologism of "mass EU immigration" is not as far-fetched as it may appear at first, does it show zero sympathy for other Europeans. However, it was still regressive because, legally speaking, the free movement of European Union citizens is not "immigration" but exercise of a citizenship right, in fact, the EU citizenship right. Reflecting on UKIP's break-through in the 2013 local elections, Farage 
attributed this success to the adding of "immigration" to the protest party's original "hard Euroscepticism": "It took me bloody years to get immigration and Europe together but I knew...that it was now the same thing" (in Ford and Goodwin 2014, p. 90).

Britain's transformation from "zero immigration country" to one that underwent what Farage called "mass EU immigration" was the unintended consequence of deliberate policy choice under New Labour. This outcome is interesting in at least two respects. First, it shows that European migration could turn out as controversial as nonEuropean migration. The magnitude of migration may matter just as much as its ethnic or racial composition. When the Blair government decided, for reasons of good neighborliness but above all in light of acute labor shortages, not to impose a temporary moratorium on migrants from the new Eastern member states in 2004, in contrast to most other Western European member states, this was at one level merely the result of wrong numerical forecasting (see Wright 2012, p. 743). However, what also proved wrong was the more latent ethno-racial rationale of this choice: the expectation that other Europeans would cause less opposition than non-Europeans when low-skilled vacancies had to be filled for which not enough Britons were available.

Strangely unaddressed in public discourse, until 2015 extra-EU flows, including from the traditional postcolonial source countries, persistently exceeded the historically unprecedented intra-EU flows post-2004. This led Eric Kaufmann (2018, p. 182) to the assumption that an "anti-racist norm...deflect(ed) criticism away from Asians and Africans towards white immigrants from the EU". However, the overwhelming importance of numbers in the "Second Great Arrival" (Goodhart 2013, Chapter 5) cannot be overlooked. If the first postcolonial arrival had brought 2 million new people to Britain, the new-millennium wave added the double amount of 4 million, and this in 15 not 50 years. This "quite literally changed the face of Britain". ${ }^{5}$

Next to underestimating the power of numbers, there was a second flaw in the design of New Labour's expansive immigration policy. This is the assumption that immigration, if only properly "managed" as legal labor migration, would take pressure off an overcharged asylum system and put to rest a vitriolic tabloid campaign against "bogus" asylum-seekers that was gearing up in the late 1990s. Randall Hansen (2014, p. 208) sarcastically referred to this thinking as "a theory that was being passed around seminar rooms at the time", namely that "expanding unskilled immigration would take pressure off the asylum queues". The problem with this "theory" is twofold. First, the "massive disparities in wealth" between sending and receiving countries make it unlikely that any "opening of unskilled migration channels" could ever be sufficient to meet demand (Hansen 2014, pp. 208-9). Secondly, as a summary account of immigration policy under Blair put it, "the public did not, as the government had anticipated, readily tell the difference between an asylum-seeker, a migrant worker or an internal student in their neighbourhood" (Spencer 2007, p. 349).

Right after entering office in 1997, Blair's New Labour countered a historical peak of asylum requests with one of Europe's most restrictive refugee policies, which included carrier sanctions, the limitation of appeal rights, forced detention and dispersal, and replacing cash benefits with vouchers. This was on the assumption that economic migrants should be deterred from using the asylum route. However, while the number of new asylum claimants fell, from 103.000 in the peak year 2002 to 23.500 in 2006, the "tabloids

${ }^{5}$ Finch and Goodhart quoted in Consterdine (2015, p. 1434). 
continued to headline anti-asylum-seeker stories on a regular basis" (Spencer 2007, p. 348f). Because asylum reform required primary legislation, which arrived in three laws passed in 1999, 2002, and 2004, there was a "consistently high profile" to the topic that fueled "contentious and divisive political debate" (ibid. 348). And even if the government excelled in "tough rhetoric", this only had the effect of "wind(ing) up" public concerns instead of "reassure(ing) them", as one observer commented (in ibid. 349).

Parallel to being hyper-restrictive on asylum, New Labour opened up in a big way for economic migration. This was not only to take pressure off the asylum system, according to the mentioned "seminar-room theory", but it was an entirely new approach to immigration, from the "control" to the "management" of migration in the country's economic interest (see Balch 2009, p. 617). Part of a larger "Cool Britannia" campaign that married a multicultural diversity agenda with economic neoliberalism, the attempt was to "rub the Right's nose in diversity and render their arguments out of date". 6 Labour leader Ed Miliband later confessed that this was an error: "We were dazzled by globalization and too sanguine about its price."7

Crucially, New Labour's immigration policy included not only the foray, found everywhere in the OECD world, into high-skilled and student migration, but also the expansion of low-skilled migration, the most fateful element of which was unhindered access to Britain for the citizens of the A8 countries joining the EU in $2004 .^{8}$ This had to spell trouble. In 2009, when "immigration" already ranked as one of the top three concerns facing the country, a survey found that almost $60 \%$ of the public "strongly" or "somewhat supported" reducing the number of unskilled migrant workers (Ford et al. 2015, p. 1398). Public fears in this respect were not entirely unfounded. In the lowly-regulated and flexible British labor market, the impact of new millennium migration on salary levels, while overall negligible, was still felt in the lowest wage segment (see Manow 2018, p. 128). Accordingly, the Leave vote in the 2016 Brexit referendum was "systematically higher" in the industrial Midlands, where wages are low and unemployment is high (ibid. 129).

Continuously rising net migration, with an all-time peak of 336.000 exactly in the 12 months preceding June 2016, was an entirely new phenomenon in the UK. Even in the heyday of postcolonial immigration in the 1960s, net migration had been small or even negative because of high levels of British out-migration. Steeply increased net migration since the late 1990s, when New Labour came to power, went along with "immigration" becoming one of the top concerns facing the country in the eyes of the British public. Whereas in 1997 only 3 $\%$ had listed immigration and race as among the top-three concerns, in 2002, at the height of a (relatively) large asylum inflow, the figure was up to 39\%; and in 2006, two years into the Eastern European inflow, 40\% of the public deemed immigration the most important single issue facing Britain (Spencer 2007, pp. 341 and 348). By late 2015, when net migration reached its record level, a whopping $63 \%$ of Britons ranked immigration as the most pressing issue of the day, way ahead of healthcare (39\%) and the economy (33\%) (Clarke et al. 2017, p. 11).

Late New Labour tried to stem the tide with a new emphasis on "controlling our borders" (Home Office 2005), and a new points-based system, modelled on Australia, was

\footnotetext{
${ }^{6} \mathrm{~A}$ former advisor and speechwriter of Tony Blair, quoted in Kaufmann (2018, p. 150).

${ }^{7}$ Quoted in "UK Immigration", Financial Times, 25 June 2012, p.8.

${ }^{8}$ A8 workers were merely asked to register under the Accession State Worker Registration Scheme, which was in place between 2004 and 2011 to keep track of the labor market effects. While registration was mandatory, failing to do so was not prosecuted.
} 
said to "ensure that only people Britain needs can come to work and study". ${ }^{9}$ When Bulgaria and Romania joined the EU in 2007, the mistake of 2004 was not repeated and free movement from these countries remained restricted during their first 7 years of membership. And Blair's intra-party successor, Gordon Brown, speaking to the Trade Union Congress (TUC) in 2007, promised the creation of 500.000 "British jobs for British workers" (Smith 2008, p. 425).

However, by that time immigration had long become a "wedge issue" (Hansen 2014, p. 200) busily exploited by the Conservative Party in opposition. Initially, this was with little success. In sync with the right-wing tabloid hysteria, the 2001 and 2005 Tory election campaigns were "populist" on immigration and asylum, depicting Labour as "hopelessly out of touch" with the people (Bale et al. 2011, p. 398). But this was to no effect. Labour easily won both elections, and Tony Blair could sneer, in 2005, that "The Tory Party have gone from being a One Nation Party to being a one-issue-party" (Hansen 2014, p. 210).

The page turned when David Cameron took over the Conservative leadership in late 2005, intent on remedying the Tories' "nasty party" image with a more moderate if, in essence, still populist line on immigration. On the moderate side, he committed himself to a "multiracial Britain" that he deemed "a success", with immigration set to "continue", yet in a "controlled" manner (Bale et al. 2011, p. 404). Anticipating the winds of Brexit, Cameron deemed the immigration problem more one of "levels" than of "different colours", in particular, one of crowded "services": "It's the pressure on schools, pressure on hospitals, pressure on housing" (ibid. 401). Perfectly in line with this diagnosis, the 2010 Conservative Manifesto promised to "take steps to take net migration back to the levels of the1990s-tens of thousands a year, not hundreds of thousands". This was to be achieved within just one parliamentary period, that is, by 2015 (ibid. 399).

But this was not moderate at all. After Blair's liberal wager that large-scale but "managed" migration would be publically acceptable, Cameron's volte-face was the second fateful political choice that prepared the road toward Brexit. While the Tories' exploitation of public concerns about large-scale migration "clearly contributed" to Labour's "heavy defeat" in the 2010 election (Bale 2014, p. 296), the "tens of thousands" pledge was impossible to meet. With a net migration figure of ca. 250.000 at the time, not only the high EU component but also constitutional commitments to non-EU asylum and family migration stood in the way. Because non-EU low-skilled migration had already been closed down under late New Labour, Cameron, with his Home Minister, Theresa May, had to go against high-skilled and student migration to fulfill the Tories' impossible pledge, even though these migrations were not publically opposed and controversial at all. A second offshoot of the "tens of thousands" campaign was the infamous order by May's Home Office to create a "hostile environment" for illegal migrants. This enlisted teachers, doctors, employers, and landlords in sniffing-up these migrants, and shamefully erroneous expulsion notices were issued to postcolonial-generation migrants, who had been long settled in the UK, but who had never been officially furnished with legal residence papers. ${ }^{10}$

Despite a whirlwind of restrictive, even draconian measures, the "tens of thousands" pledge could not remotely be achieved. After a temporary lull, from 2013 on the net migration figures even reached new heights, crossing the 300.000 mark in 2014. This

\footnotetext{
${ }^{9}$ Immigration Minister Liam Bryne, quoted in Smith (2008, p. 425).

${ }^{10}$ Jessica Elgot, “Theresa May's 'Hostile Environment' at the Heart of Windrush Scandal”, The Guardian, 17 April 2018.
} 
was due to two factors impossible to control for the government: first, a new wave of European Debt Crisis migration from southern member states, particularly Spain; and, secondly, the end of the seven-year moratorium on Romanian and Bulgarian free movement after these two countries had joined the EU in 2007. With their "tens of thousands" pledge, the Conservatives had inadvertently produced their own wedge issue, whetting the appetite for a drastic reduction of immigration that was picked up by the ferociously anti-EU and anti-immigration tabloids and, of course, by the populist UK Independence Party. Overall, Britain's immigration policy under the Conservative Cameron government must be considered a paradigmatic case of an immigration policy dictated by hostile public opinion, which in the UK was even stronger opposed to immigration than in "any other large European country". ${ }^{11}$

The third political choice laying the tracks for Brexit was David Cameron's 2015 election pledge to hold a referendum over Britain's EU membership. This was a Faustian bargain to silence the Eurosceptics in his party; they should "stop banging on about Europe" ${ }^{12}$ Cameron hoped to silence them with pre-referendum concessions from the EU, most notably about migration. As is well known, "Dave's deal" flopped (Evans and Menon 2017, pp. 47-51). Instead of a stop of childcare allowance for families abroad, he only got a cost-of-living-adjustment possibility; more crucially, instead of a categorical fouryear exclusion of EU foreigners from welfare, he only got a temporary "alert and safeguard" mechanism in cases of inflows of "exceptional magnitude"; and to add insult to injury, the "emergency brake" could only be triggered by the European Commission (Dennison and Geddes 2018, p. 1146). The possibility to control intra-European flows, the central issue of the Leave campaign, wasn't even put on the agenda. "It Stinks", wrote the Sun, "The Great Delusion" was the headline in the Daily Mirror, and 54\% of the surveyed British public felt the concessions would "make no real difference" (Clarke et al. 2017, p. 26).

Accordingly, Cameron's pro-EU campaign fell silent on the migration and the closely related national sovereignty issues. Instead, it evolved as "Project Fear", according to which "leaving Europe would threaten our economic and our national security" (Cameron in Clarke et al. 2017, p. 30). This instrumental focus perfectly mirrored that even among eventual Remain voters "strong attachment to the EU" figured as the least important of four suggested reasons for their choice (the most important being risks connected to "economy, jobs and prices") (Carl et al. 2019, p. 289). However, it dodged the central concerns of the small majority of $51.9 \%$ of British voters who eventually voted for "Leave" in June 2016. When asked about their motivation, $68 \%$ of them said they did so out of a concern about migration. This was second only to the $74 \%$ whose first motive was sovereignty (Wöhst 2018, p. 25), dubbed "Take Back Control" in the UKIP-led "Leave.eu" branch of the Leave campaign. ${ }^{13}$ So strong was the anti-immigration impulse of Leave-voters, that $35 \%$ of them claimed to be prepared to accept a $5 \%$ reduction of their income if only EU migration was reduced to zero (Kaufmann 2018, p. 201).

Perhaps the strongest and ultimately decisive image in this most dramatic episode of modern British history is the ignominious "Breaking-Point" poster of the Leave.eu

\footnotetext{
11"The Tories` Barmiest", The Economist, 20 October 2012, p.14.

${ }^{12}$ David Cameron, quoted in Dennison and Geddes (2018, p. 1143).

${ }^{13}$ The official leave campaign was "Vote Leave", which focused more on sovereignty and free trade deals with emergent countries. One of its most prominent figures, Boris Johnson, described himself as "passionately pro-immigration and pro-immigrant" (quoted in Kaufmann 2018, p. 194).
} 
campaign, published shortly before the referendum date. Poaching on the 2015 Syrian refugee crisis that raged in Continental Europe, the poster shows hordes of darkskinned asylum seekers in Slovenia heading toward the Austrian border: "We must break free of the EU and take back control of our borders", can be read at the bottom. This was populism, pure and simple, spreading false information and demagogic. To remember, the UK government had opted out of all inconvenient provisions under EU immigration law, was not part of the Schengen Area, and in principle could send back any asylum-seeker to her first EU country under the Dublin Convention of which the UK was a member. Brexit, in reality, would reduce the possibility of the UK government to control the entry and stay of certain third-country nationals, most notably asylumseekers. This is because, at a minimum, "Dublin" will not be "for free any longer", as Daniel Thym pointed out (2017, p. 2).

The typical Leave voter had no academic degree (78\%), was dependent on social housing (70\%), had an income below 1200 Pounds monthly (66\%), and was over 65 years old (61\%) (Wöhst 2018, p. 25). These were not the winners of Britain's neoliberalism that had started with Thatcher and that was driven to new heights under Blair-"Thatcher in trousers", as Marxist historian Eric Hobsbawm dismissively called the latter. Cameron's successor, Tory Prime Minister Theresa May, and after her Boris Johnson, stubbornly vowed to deliver the Brexit that Leave voters wanted. "To get Brexit done", was Boris Johnson's mantra-like promise at the historical December 2019 elections, which he won by large margins. He delivered on his promise within 2 months, the UK officially leaving the EU on 1 February 2020.

It is sometimes overlooked that, in ideological terms, Johnson took a page from his luckless predecessor, Theresa May, who was weirdly globalist and populist in tandem. Already May had packaged Brexit as a quest for a truly "Global Britain", while simultaneously acting on behalf of the "people down the road" who were loathing "the international elites". Here is May's famous line at the 2016 Conservative Party Congress in Birmingham, which could have been written by David Goodhart: "But if you believe you're a citizen of the world, you are a citizen of nowhere-you don't understand what citizenship means". ${ }^{14}$

With respect to immigration's role in Brexit, the experience of massive and sudden migration after 2004, particularly in economically depressed areas that had not seen it before, strongly correlated with a preference for Brexit. Consider Boston, a small town of 35.000 in the East Midlands, with vegetable and potato fields that are worked by farm hands from Poland. 75.6\% of Bostonians voted for Brexit in June 2016, which was the highest score in the UK. Boston had seen its migrant population grow sixteen-fold between 2005 and 2015, from 1000 to 16.000 (Goodwin and Milazzo 2017, pp. 454-5; Wöhst 2018, p. 31). These may be small numbers, but their exponential increase is remarkable. After the vote, journalists from all over the world fell into this hapless place to explore the secrets of Brexit. They found a place distressed by low wages and high living costs, strained public services and scarce housing, with much talk about recently increased crime rates. And they found a place with extreme ethnic segregation, the Poles shopping in their own supermarkets and hanging out in their own pubs. A few days after the referendum, a Polish-

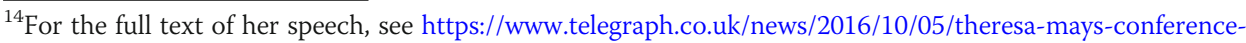
speech-in-full/.
} 
Italian owner of a local taxi company, who had lived in Boston for 16 years, found this note on his car's windshield: "Did you pack your bags yet?"15

A much less known but highly interesting element in the demography of the Brexit referendum is the Asian vote. Some districts with South Asian populations exceeding 25\% delivered solid Leave votes, including Bradford, Slouth, or Luton. This outcome might be explained by the usual socio-economic variables. But some places in West London, where the level of education and prosperity would lead one to expect Remain votes, but which have a "noticeable South Asian presence", still voted Leave (Ehsan 2017). This dynamic is as yet unexplored. However, why should prosperous ethnics of Indian, Pakistani, or Bengali background feel and vote pro-European? They had been taught to adopt "British values", and some of their intellectuals, like Tariq Modood or Bhikhu Parekh, have praised British multiculturalism in distinctly nationalist terms. As their circuit spanned Britain and South Asia, but not the European continent, what should the provincial project of taking from European borders "their rigidity and...intransigent hostility", as the European Saint Robert Schuman had envisioned (in Geddes 2014, p. 290), mean to them? Some Leave campaigners shrewdly courted the Asian minorities by denouncing a "racist" immigration system that allowed white EU migrants to enter the UK freely, while those from the Indian subcontinent were subjected to visa and work restrictions (see Ehsan 2017).

Striking exactly this chord, the UK's "future skill-based immigration system", first presented in December 2018 and in essence adopted in early 2020, wants to be "a system where it is workers' skills that matter, not which country they come from". ${ }^{16}$ In the assumption that only after leaving the European Union a truly non-discriminatory immigration policy is possible, ${ }^{17}$ the primal non-participation of Britain in the European project comes full circle. The post-Brexit immigration policy will naturally court highskilled immigrants, while discarding "an explicit work migration route for low-skilled workers" (MAC 2018, p. 5). While this caused some stir when officially announced in February $2020,{ }^{18}$ it only aligns Britain with the two-pronged immigration policy that is now standard across rich OECD societies.

Not accidentally, the notion of a "Australian-style points based immigration system"19 was spread with great fanfare by Boris Johnson, who had been curiously pro-migration throughout the entire Brexit campaign (and, of course, prior to that, during his time as Mayor of London). However, this was not the novelty as which Johnson presented it. In reality, a points-based system had been in place since 2008. Only, over time it had devolved from a system of "tradeable points" into one where successful applicants had to "meet all criteria", most importantly, skills and a job with a minimum salary at hand. This had made the points that were still formally attached to these criteria, well, pointless (MAC 2020, p. 1). In January 2020, the Migration Advisory Council recommended to retain this system, with or without points, which it deemed merely a question of "cosmetics" (ibid. 6).

\footnotetext{
${ }^{15}$ Kimiko de Freytas-Tamura, "After 'Brexit' Vote, Immigrants Feel a Town Turn Against Them”, New York Times, 9 July 2016.

${ }^{16}$ From the foreword by Prime Minister Theresa May (Home Office 2018, p. 3).

${ }^{17}$ Of course, this non-discrimination talk is little more than a ploy. For the many indirect ways in which formally non-discriminatory immigration policies may still be discriminatory, see Ellermann and Goenaga (2019).

${ }^{18}$ Larry Elliott, “The New UK Immigration Rules Tell Employers to Suck it up”, The Guardian, 18 February 2020.

${ }^{19}$ Heather Stewart et al., “Conservative Party Manifesto”, The Guardian, 25 November 2019.
} 
In a nutshell, no fundamental reorientation of British immigration policy is in the making. Except that due to the end of free movement for Europeans, this policy will have to be more expansive than in the past to meet the UK's economic needs. Tellingly, the poisonous "tens of thousands" pledge, which helped catapult the UK out of the EU, has in the meantime been quietly dropped.

\section{Trump}

The best barometer of a liberal immigration policy is what Gary Freeman (1995, p. 894) has called the "anti-populist norm". It prescribes "constrained" discourse over immigration, in particular, precluding "argument over the ethnic composition of migrant streams". The Brexit campaign, which was more about the quantity than the quality of recent (EU) migration to Britain, largely observed the anti-populist norm, and it even made a less "discriminatory" immigration policy one of its selling-points. By contrast, the rise of Trump has implied the complete demolition of the anti-populist norm. The "exploit(ation) (of) racial, ethnic, or immigration-related fears in order to win votes", which according to Freeman is verboten (ibid. 886), figured centrally in Trump's 2016 election campaign, with Mexicans as "bad hombres" and an "Islam (that) hates us". Does this herald the return to a racially discriminatory immigration policy that Western states had abandoned over half a century ago?

The most serious test case is the "Muslim Ban", later sanitized as "Travel Ban". On his campaign trail, Trump had infamously promised a "total and complete shutdown of Muslims entering the United States". Upon signing Executive Order No. 13769 (henceforth EO-1), one of his very first acts after assuming office in late January 2017, Trump read its title aloud: "Protecting the Nation from Foreign Terrorist Entry into the United States", then looked up and said "We all know what that means". ${ }^{20}$ What "that means" is the swift fulfillment of one of his most controversial and inflammatory election promises. This was also one of the most chaotic episodes in a presidency that has not been short of them. EO-1, with immediate effect, barred from entry into the US all citizens of seven Muslim-majority countries, even if they were visa holders or legal permanent residents returning from a visit abroad. Because Trump and his advisors had not consulted with government lawyers beforehand and not applied the usual intraexecutive legal process, the result was "chaos in American airports". ${ }^{21}$ Over 700 travelers were detained or put back on the next return flight, and about 60.000 visa were "provisionally revoked". The courts that immediately stalled the order, took the absence of ordinary legal process itself as "evidence of a discriminatory motive" (Eggleston and Elbogen 2018, p. 835). When the Department of Homeland Security (DHS), which like all other government agencies had not been consulted, arrived to the legal conclusion that legal permanent residents had to be excluded from the order, this was immediately overruled by Trump's "inner circle", Stephen Miller and Steven Bannon; they decreed that green card holders could be admitted only on a "case by case basis". ${ }^{22}$ In this remarkable moment, the rule of law was quite literally lifted in favor of the rule of populists, and of known white supremacists at that.

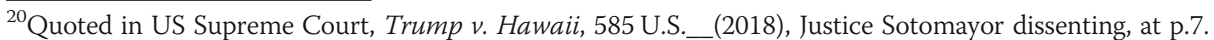

${ }^{21}$ "Chaos at Airports as America Introduces Travel Ban", The Economist, 30 January 2017.

${ }^{22}$ Evan Perez et al., "Inside the Confusion of the Trump Executive Order and Travel Ban", CNN, 30 January 2017.
} 
To meet the most elementary due process objections, a second version of the travel ban (EO-2), issued in March 2017, applied only to those who lacked a valid visa at the order's effective date and it did not include legal permanent residents; in addition, Iraq was removed from the list of excluded countries because of its "close cooperative relationship" with the US. Like its predecessor, EO-2 was immediately blocked in court, on statutory and constitutional grounds. However, in June 2017 the Supreme Court, which accepted to review the case, temporarily lifted the lower court injunctions, except for those who held a "credible claim of a bona fide relationship" with a person or entity in the United States. Accordingly, the government had a relatively free-go as long as America's highest court had not made up its mind. In September 2017, a "Proclamation" (EO-3) replaced EO-2, which had been meant to be valid for 90 days only. Sudan was dropped from the list of excluded countries, while Chad, North Korea, and Venezuela were added to the original core of Iran, Libya, Somalia, Syria, and Yemen. Including two non-Muslim countries was an obvious move to rebut the charge of "anti-Muslim animus" that lower courts had brought to justify their injunctions. Similarly, a tailored approach of excluding only certain but not all entry possibilities for the citizens of the prohibited countries, apparently strengthened the government claim that not religious animus but "national security" was the driving concern. In December 2017, the Supreme Court upheld also this third and latest version of the Travel Ban pending its final decision, but this time in full.

Before the courts, the government made three arguments in defense of the Travel Ban, which are in the order of a logical progression (see Cole 2018). First, and most fundamentally, courts were not competent to review in the first, as it was in the sovereign power of the political branches of government to decide about matters related to immigration and foreign affairs. Since it was first formulated in the late nineteenth century Chinese Exclusion Case, this was known as the "plenary power" doctrine. As Justice Fields had argued in the 1889 Chinese Exclusion Case, the "highest duty of every nation" resided in efforts to "preserve its independence, and give security against foreign aggression and encroachment", and courts were not allowed to impair the federal government in this task (quoted in Margulies 2018, p. 27). This was no American idiosyncrasy. Already Emer de Vattel, the Swiss eighteenth century inventor of international law, had considered the control of immigration as a "logical corollary" to "rights of domain and sovereignty" (quoted in ibid.). In the meantime, however, human rights and non-discrimination have advanced as co-constitutive principles of political order, next to sovereignty. To a degree, even the US Supreme Court acknowledged them as constraining the "plenary" immigration power of the government. ${ }^{23}$ As the Travel Ban made its way through the courts, this was to become a test case whether the retreat of plenary power would continue or be halted.

Secondly, the government argued that, even if courts did review what it deemed unreviewable, the external statements of the President, from which the plaintiffs had plausibly deduced that religious animus undergirded the Travel Ban, did not count. Only the text of the Proclamation (EO-3) should count, which "says nothing about religion."24

\footnotetext{
$\overline{{ }^{23} \text { Zadydas v. Davis (533 US } 678}$ [2001]).

${ }^{24}$ Trump v. Hawaii, syllabus at p.5.
} 
And, thirdly, even if courts did consider these external statements, the detailed visavetting review by the Department of Homeland Security under EO-2, which merely identified countries that did not sufficiently cooperate in providing security-relevant information about their nationals or that themselves were suspected to be "a state sponsor of terrorism", had sufficiently neutralized or "laundered" any impermissible intent on part of the President (Cole 2018, p. 4).

Stunningly, in its final decision, Trump v. Hawaii (2018), the Supreme Court followed the government argumentation almost in full. It thus did its share to "normalize[] the Trump presidency", as Peter Spiro (2019, p. 113) appositely argues. In coming to its conclusion, the court had to rebut two claims made by plaintiffs and which had previously been accepted by lower courts: that the President had acted outside of his statutory authority as granted by the Immigration and Nationality Act (INA); and that his action was in violation of the constitutional Establishment Clause that prohibits religious discrimination.

With respect to the statutory question, $\$ 1182(\mathrm{f})$ of INA grants the President authority, "for such period as he shall deem necessary", to "suspend the entry of all aliens or any class of aliens" if he deems their entry "detrimental to the interests of the United States". The question is whether this authority is only "interstitial" and limited to crisis situations, as argued by the plaintiffs and held by lower courts; or whether it is "permanent" and general, as implied in the Travel Ban and as eventually upheld by the Supreme Court. Certainly, "(b)y its plain language", this clause "grants the President broad discretion to suspend the entry of aliens into the United States", as the Supreme Court majority defended its more sweeping interpretation of the scope of the clause. However, never before had a government pushed this line; all previous invocations of $\$ 1182(\mathrm{f})$ had been of the "interstitial" kind. One example is when President Reagan temporarily banned the entry of "all Cuban nationals" in retaliation for the Mariel Boat Lift, in which Castro had flooded the US with Cuba's near-total prison population. A second "interstitial" example is when President Carter barred Iranians from entering the US during the Iranian Hostage Crisis. The problem is that, thirteen years after 9/11, fifteen of whose 19 attackers notably hailed from a Saudi Arabia that President Trump at no point had considered to include in his "Travel Ban", there plainly was no crisis situation to justify not merely the temporary exclusion of a tiny island population, like the Cubans, but of some 150 million people worldwide, and possibly in permanence.

A second statutory issue to resolve was whether the Travel Ban entailed a violation of the non-discrimination clause under INA, $\$ 1152(\mathrm{a})(1)$ (A), which stipulates that "no person shall...be discriminated against in the issuance of an immigrant visa because of the person's race, sex, nationality, place of birth, or place of residence." Apparently, the Travel Ban categorically excluded on the basis of nationality, so that it constituted discrimination under the clause. At least, so argued the plaintiffs and lower courts. To counter this objection, the Supreme Court majority made a distinction between "admissibility determinations" and "visa issuance", arguing that the non-discrimination clause applied only to the latter, but not the former. Therefore, it couldn't be a constraint on the government's authority to exclude entire “class(es) of aliens" under $\$ 1182(\mathrm{f})$. The federal court that was overruled in this decision begged to disagree. It followed the plaintiffs' argument that the broad authority delegated to the government under INA could not be allowed to become a "wrecking ball" against an immigration statute that, 
from the mid-1960s on, had solemnly abdicated the racially motivated national-origin quota system of the past. Indeed, EO-3 "ominously echoes the national origin quotas that Congress rejected in 1965" (Margulies 2017).

However, the main question before the court was not statutory but constitutional: did the "Travel Ban", which by Trump's own admission was a "morphed" ${ }^{25}$ version of the "Muslim Ban" that he had promised in his campaign, inhere the "unconstitutional purpose of excluding Muslims"? ${ }^{26}$ It is at first puzzling that the religious discrimination charge was made under the First Amendment's Establishment Clause and not its Free Exercise Clause, because the focus of the former is on "institutions" but not "individuals" (Maltz 2018, p. 407) ${ }^{27}$ However, if the "clearest command" of the Establishment Clause is that "one religious denomination cannot be officially preferred over another" ${ }^{28}$ the religious discrimination charge could be made through the institutional angle also. In fact, by this interpretation of the Establishment Clause, Trump had violated it in all openness. This is because the first version of the Travel Ban also included a 120-day ban on all refugee acceptance, after which period "religious minorities" were to be preferred. To allow no doubt about the true meaning of this neutral formulation, on the day of signing the ban Trump explained that it entailed a preference for "Christian" refugees in Muslim-majority states. But " $(t) h i s$ is analogous to declaring the United States a Christian country", as Noah Feldman exclaimed. ${ }^{29}$

The religious discrimination charge fed exclusively on external statements by Trump, made in the course of his campaign and even later in office. These statements were unequivocal. The infamous "total and complete (Muslim) shutdown" statement had remained on his campaign website until May 2017, five months after the issuance of the first "Travel Ban". Still on his campaign trail, when asked whether his new insistence on "extreme vetting" meant "pulling back" from the "Muslim Ban", Trump responded: "I actually don't think is (sic) a rollback. In fact, you could say it's an expansion...people were so upset when (I) used the word Muslim.."30 Freshly elected, when asked whether he would "rethink" his plans to "ban Muslim immigration", the response was: "You know my plans. All along. I've proven to be right". ${ }^{31}$ Having signed the second version of the Travel Ban in March 2017, for anyone who would not have noticed, Trump established the direct link to his "campaign promises": "I keep my campaign promises, and our citizens will be very happy when they see the result" ${ }^{\text {"2 }}$--though he himself wasn't happy about a "watered down, politically correct version" of the "original Travel Ban." ${ }^{33}$ Trump's frustration about hiding his real intent behind neutral language and about having to make other compromises did not diminish when the final "Proclamation" was issued in September 2017: "The travel ban into the United States should

\footnotetext{
${ }^{25}$ Trump v. Hawaii, dissent by Justice Sotomayor, at p.6 (quoting Trump).

${ }^{26}$ Trump v. Hawaii, majority opinion of Chief Justice Roberts, at p.24.

${ }^{27}$ Harvard constitutional lawyer Noah Feldman, in one of the first critical responses to the first version of the Travel Ban in January 2017, held it to be "violating both the equal protection and free exercise clauses" (N.

Feldman, “Trump's Travel Ban is an Attack on Religious Liberty”, Bloomberg, 30 January 2017).

${ }^{28}$ Trump v. Hawaii, majority opinion, at p.26.

29"Trump's Travel Ban is an Attack on Religious Liberty", op. cit.

${ }^{30}$ Trump v. Hawaii, dissent by Justice Sotomayor, at p.6 (quoting Trump).

${ }^{31}$ Ibid.

${ }^{32}$ Ibid., p.8 (quoting Trump)

${ }^{33}$ Ibid., p.9 (quoting Trump).
} 
be longer, tougher and more specific-but stupidly, that would not be politically correct." ${ }^{34}$ The original hint to move from "Muslims" to "territory" obviously had come from his close advisor Rudolph Giuliani, former mayor of New York, who boasted on Fox News: "He (Trump) called me up. He said, 'Put a commission together. Show the right way to do it legally'." Giuliani's apparent advice was to "(focus) on, instead of religion, danger...(The order) is based on places." ${ }^{35}$

These external statements were meticulously laid out not only in the dissent by Justice Sotomayor, but in the Trump-favoring majority opinion of Chief Justice Roberts. If there ever had been a case of "religious gerrymander", ${ }^{36}$ here was one. The question was how much or how little these statements should count, or, in legal language, what standard of review should be applied by the court. The usual standard in Establishment Clause cases is that of the "reasonable observer". It was duly taken by dissenting Justice Sotomayor, who concluded on its basis "that the President was motivated by anti-Muslim animus." 37 Chief Justice Roberts, by contrast, applied a more lenient "rational basis review" standard, which "considers whether the entry policy is plausibly related to the Government's stated objective to protect the country and improve vetting processes." ${ }^{38}$ As the Chief Justice conceded, on this mild review standard "the Court hardly ever strikes down a policy as illegitimate". ${ }^{39}$ While there had been no jurisprudential precedence for this choice, Roberts deemed "rational review" the right standard simply because one dealt with an instance of "immigration policies, diplomatic sanctions, and military actions". ${ }^{40}$ In other words, the plenary power doctrine trumped all other considerations, including a discrimination charge under the Establishment Clause.

Once the choice for the "rational basis" test had been made, all that the court majority needed to find to uphold the policy in question was a "justification independent of unconstitutional grounds". ${ }^{41}$ They found it in the "national security concerns" proffered by the government. ${ }^{42}$ But not without lashing out against the "religious gerrymander" charge: the policy "covers just 8 percent of the world's Muslim population." ${ }^{43}$ The same reality, of course, looked different if differently formulated: the Travel Ban denied entry to 150 million people from six countries that were to over $90 \%$ Muslim. To bolster the government's "national security" rationale, the court correctly pointed out that even for the covered countries there were "significant exceptions" for "various categories" of foreign nationalsfor instance, students and exchange visitors from Iran, America's enemy No.1, were allowed in; and there was a waiver program for all foreign nationals covered, so that each individual, in principle, could make her bid for entry. ${ }^{44}$

\footnotetext{
${ }^{34}$ Ibid.

${ }^{35}$ Trump v. Hawaii, majority opinion by Chief Justice Roberts, at p.27, quoting "one of the President's campaign advisers", who was Giuliani.

${ }^{36}$ This was the plaintiff charge, quoted in ibid., at p.26.

${ }^{37}$ Trump v. Hawaii, dissenting opinion by Justice Sotomayor, at p.1.

${ }^{38}$ Trump v. Hawaii, majority opinion by Justice Roberts, at p.32.

${ }^{39}$ Ibid., at p.33.

${ }^{40}$ Ibid., at p.32, fn. 5 .

${ }^{41}$ Ibid., at p.32.

${ }^{42}$ Ibid., at p.34.

${ }^{43}$ Ibid.

${ }^{44}$ Ibid., pp.36-37.
} 
However, these considerations could be equally turned against the government. Some of the exempted categories were known to constitute higher risk factors than others that were included in the ban. In a separate dissent, Justice Breyer laid out that the "elaborate system of exemptions and waivers" were not "applied" as they were "written"; thereby "the claim that the Proclamation is a 'Muslim ban', rather than a 'security-based' ban, becomes much stronger." 45 For example, the number of individual waivers was miniscule, and this by explicit order-in the final Proclamation's first month, there were only 2 waivers out of 6555 eligible applications. ${ }^{46}$ Moreover, two internal Department of Homeland Security (DHS) memos, written just before the issuance of the second version of the Travel Ban in March 2017, pointed out that citizens of the excluded countries were "rarely implicated in USbased terrorism" (under 15\%), and that "citizenship" in general was "no good indicator of terror threats"; most foreign US-based extremists "radicalized several years after their entry to the United States". ${ }^{4}$

The majority court might counter that it was not up to judges to adjudicate on the wisdom of policy-"We express no view on the soundness of the policy", Chief Justice Roberts blithely stated. ${ }^{48}$ However, from the ultimate chaos of its first enunciation on, the Travel Ban has all the appearance of a hastily assembled package that serves a different, essentially polemical purpose. It epitomizes Trump's entire immigration policy, which is not geared to serve any substantive purpose, but to rally nativism, campaign-style. Among those who shared the majority opinion in Trump v. Hawaii, alone Justice Anthony Kennedy, the long-time "swing vote" who mediated between the conservative and liberal camps on the Supreme Court, uttered an oblique word of critique. Even if "Government officials" are not always "subject to judicial scrutiny or intervention", as they apparently were almost not in this case that resurrected the plenary power doctrine, " $(\mathrm{t})$ hat does not mean those officials are free to disregard the Constitution and the rights it proclaims and protects" ${ }^{49}$ Furthermore, "(a)n anxious world must know that our Government remains committed always to the liberties the Constitution seeks to preserve and protect, so that freedom extends outward, and lasts" ${ }^{50}$ This was the last sentence in the last opinion of Justice Kennedy, who has since retired from the Supreme Court. He was replaced by an unambiguously Trump-servile justice who has cemented the conservative majority in America's highest court for decades to come. Trump v. Hawaii ended in a "near-complete legal victory for the Trump administration" (Spiro 2019, p. 112), and a since recomposed Supreme Court, with the strongest conservative majority since earlier in the twentieth century, is unlikely to get into its way in the future. ${ }^{51}$

\footnotetext{
${ }^{45}$ Trump v. Hawaii, dissent by Justice Breyer, at p.3.

${ }^{46}$ Ibid., at p.4.

${ }^{47}$ The DHS memos are quoted by Cole (2017, p. 6).

${ }^{48}$ Trump v. Hawaii, majority opinion by Justice Roberts, at p.38.

${ }^{49}$ Trump v. Hawaii, concurring opinion by Justice Kennedy, at p.1.

${ }^{50}$ Ibid., p.2.

${ }^{51}$ However, under a newly centrist chief justice Roberts, who has taken on the mediating role that had previously been played by Kennedy, the Supreme Court has recently issued surprisingly liberal decisions on LGBT rights and abortion. This may be interpreted as "preserving the court's independence" ("Hail to the Chief", The Economist, 4 July 2020, p.34).
} 


\section{Conclusion}

Of our two cases of immigration in the populist crucible, the story of Brexit demonstrated that, if the size of the inflow exceeds the level of what is deemed acceptable, resentment may be directed against migrants from nearby just as easily as against migrants from afar. Brexit, however, while of dramatic import for Britain and Europe, does little to change the structure of immigration policy in a neoliberal age, nor does it challenge its persistent liberal basis-except that it may make the policy more universalistic, if one holds a negative view on preferential treatment for other Europeans. As we argued, the Brexit referendum was "largely, if not entirely, about reducing immigration" (Evans and Menon 2017, p. 121). However, one should not ignore that it was also a classically populist revolt, on populism's "vertical" anti-elite rather than its "horizontal" anti-immigrant axis (for this distinction, see Brubaker 2017). In the first British referendum about EU membership, in 1975, the electorate "took the advice of people they were used to following", as Roy Jenkins put it memorably (Evans and Menon 2017, p. 71). By contrast, this time around the elite advice to vote for Europe may have turned the electorate against Europe even more. A most striking facet of the 2016 referendum vote is that three-quarters of who favor the death penalty, which is entirely taboo at the British-cum-European elite and institutional levels, also voted for leaving the EU (ibid. 74). This suggests that the vote expressed a larger disaffection of ordinary people with a political elite that is united across party lines by a "socially liberal, pro-market consensus" (ibid. 122), the all-party "party of Davos". ${ }^{52}$ Having ruled Britain for the past 40 years, the party of Davos was thrown out with Brexit. For how long remains to be seen.

By contrast, Trump's immigration policy is the most openly populist and discriminatory that can be found anywhere in the Western world. But it also demonstrates how much leverage for it exists within the given statutory framework. Remarkably, not a single legislative change was required to make it possible. It could even build on foundations, particularly in its enforcement bent (that could not be discussed here), which had been laid by previous Democratic governments, from Clinton to Obama (see Waldinger 2018). The "Muslim" or "Travel Ban" is still the most problematic of all populist interventions in a Western state's immigration policy to date. However, it passed constitutional muster only by denying its racially or religiously discriminatory intention, which means that its formal prohibition is still in force. The most conservative Supreme Court in living memory was required to come to this result, including a breathtaking level of ignoring the obvious on its part. Yet, to repeat the essential point, it was a facially neutral "Travel Ban", no directly discriminatory "Muslim Ban", that came to be licensed by the court. Accordingly, it does not mark a return to the openly racist immigration policy of the pre-1960s period. It is also noteworthy that pluralist American institutions, from recalcitrant federal courts to "sanctuary" cities and states, to the Democratic opposition in Congress to the most symbolically loaded and ludicrous of Trump's projects, the building of his "Big, Beautiful Wall" at the US-Mexican border, have so far held the line against a populist Durchmarsch.

52“The Party of Davos", The Economist, 16 November 2019, p.30. 


\section{Acknowledgements}

None.

\section{Author's contributions}

The author read and approved the final manuscript.

\section{Funding}

No external funding was used.

\section{Availability of data and materials}

No primary data were used for this article; it is entirely based on library sources.

\section{Ethics approval and consent to participate}

Not applicable.

\section{Consent for publication}

Not applicable.

\section{Competing interests}

The authors declares that he has no competing interests.

\section{Received: 30 March 2020 Accepted: 7 October 2020}

Published online: 21 December 2020

\section{References}

Balch, A. (2009). Labour and epistemic communities: the case of 'managed migration' in the UK. The British Journal of Politics and International Relations, 11, 613-633.

Bale, T. (2003). Cinderella and her ugly sisters: the mainstream and extreme right in Europe's bipolarizing party systems. West European Politics, 26(3), 67-90.

Bale, T. (2014). Putting it right? The Labour Party's big shift on immigration since 2010. The Political Quarterly, 85(3), 296-303. Bale, T., et al. (2011). Having one's cake and eating it too: Cameron's conservatives and immigration. The Political Quarterly, 82(3), 398-406. Brubaker, R. (1995). Comments on 'modes of immigration politics in liberal democratic states'. International Migration Review, 29(4), 903-908.

Brubaker, R. (2017). Why populism? Theory and Society, 46(5), 357-385.

Carl, N., Dennison, J., \& Evans, G. (2019). European but not European enough: an explanation for Brexit. European Union Politics, 20(2), 282-304

Clarke, H., et al. (2017). Brexit. Cambridge: Cambridge University Press.

Cole, D. (2017, May 11). Trump's travel bans-look beyond the text. New York Review of Books.

Cole, D. (2018, April 23). The Supreme Court's first great Trump test: The Muslim Ban. New York Review of Books.

Consterdine, E. (2015). Managed migration under Labour. Journal of Ethnic and Migration Studies, 41(9), 1433-1452.

Dancygier, R., \& Margalit, Y. (2019). The evolution of the immigration debate. Comparative Political Studies (advanced electronic publication) (pp. 1-41).

Dennison, J., \& Geddes, A. (2018). Brexit and the perils of 'Europeanised' migration. Journal of European Public Policy, 25(8), 1137-1153.

Eggleston, W. N., \& Elbogen, A. (2018). The Trump administration and the breakdown of intra-executive legal process. The Yale Law Journal Forum, 16, 825-847.

Ehsan, R. (2017, February 16). Inside the British Asian Brexit vote. The Conversation. https://theconversation.com/inside-thebritish-asian-brexit-vote-and-why-it-contains-a-few-surprises-72931.

Ellermann, A. \& Goenaga, A. (2019). Discrimination and policies of immigrant selection in liberal states. Politics and Society $47(1), 87-116$.

Evans, G., \& Menon, A. (2017). Brexit and British politics. Cambridge: Polity.

Favell, A., \& Barbulescu, R. (2018). Brexit, 'immigration' and anti-discrimination. In P. Diamond et al. (Eds.), The Routledge handbook of the politics of Brexit. London: Routledge.

Fligstein, N. (2008). Euroclash. New York: Oxford University Press.

Ford, R., \& Goodwin, M. (2014). Revolt on the right. London: Routledge.

Ford, R., et al. (2015). Public opinion, responsiveness and constraint: Britain's three immigration policy regimes. Journal of Ethnic and Migration Studies, 41(9), 1391-1411.

Freeman, G. P. (1994). Britain, the deviant case. In W. Cornelius et al. (Eds.), Controlling immigration. Stanford: Stanford University Press.

Freeman, G. P. (1995). Modes of immigration politics in liberal democratic states. International Migration Review, 29(4), 881-902. Geddes, A. (2014). The EU, UKIP and the politics of immigration in Britain. The Political Quarterly, 85(3), 289-295.

Goodhart, D. (2013). The British dream: successes and failures of post-war immigration. London: Atlantic Books.

Goodwin, M. \& Milazzo, C. (2017). Taking back control? The British Journal of Politics and International Relations, 19(3), 459-464.

Hansen, R. (2014). Paradigm and policy shifts: British immigration policy, 1997-2011. In J. Hollifield et al. (Eds.), Controlling immigration. Stanford: Stanford University Press.

Home Office (UK) (2005). Controlling our borders. London: HMSO.

Home Office (UK) (2018). The UK's future skills-based immigration system. London: HMSO

Kaufmann, E. (2018). Whiteshift. London: Allen Lane.

Lind, M. (2020). The new class war. New York: Penguin.

MAC (Migration Advisory Council) (2018, September 18). European economic area migration in the UK: final report. London: MAC.

MAC (2020, January). A points-based system and salary thresholds for immigration. London: MAC

Maltz, E. M. (2018). The constitution and the Trump travel ban. Lewis and Clark Law Review, 22(2), 391-412. 
Manow, P. (2018). Die Politische Ökonomie des Populismus [The political economy of populism]. Berlin: Suhrkamp.

Margulies, P. (2017). Ninth circuit argument turns on whether the ban clashes with the immigration act, Lawfare (Dec.7). https:// www.lawfareblog.com/ninth-circuit-argumentturns-whether-ban-clashes-immigration-act.

Margulies, P. (2018). Bans, borders, and sovereignty: judicial review of immigration law in the Trump administration. Michigan State Law Review, 1, 1-80.

Mudde, C. (2013). Three decades of populist radical right parties in Western Europe: so what? European Joumal of Political Research, 52, 1-19.

Risse, T. (2010). A community of Europeans. Ithaca: Cornell University Press.

Smith, J. (2008). Toward consensus? Centre-right parties and immigration policy in UK and Ireland. Journal of European Public Policy, 15(3), 415-431.

Spencer, S. (2007). Immigration. In A. Seldon (Ed.), Blair's Britain, 1997-2007. Cambridge: Cambridge University Press.

Spiro, P. (2019). Trump V. Hawaii, 138 S. Ct. 2302. The American Journal of International Law, 113(1), 109-116.

Thym, D. 2017, October 20. The irony of Brexit for immigration control. verfassungsblog.de. https://verfassungsblog.de/theirony-of-brexit-for-immigration-control-2/.

Wagner, M., \& Meyer, T. (2017). The radical right as niche parties? The ideological landscape of party systems in Western Europe, 1980-2014. Political Studies, 65(15), 84-107.

Waldinger, R. (2018). Immigration and the election of Donald Trump. Ethnic and Racial Studies, 41(8), 1411-1426.

Wöhst, C. (2018). Länderbericht Vereinigtes Königreich [Country Report United Kingdom]. Dresden: Mercator Forum Migration und Demokratie (MIDEM).

Wright, C. F. (2012). Policy legacies, visa reform and the resilience of immigration politics. West European Politics, 35(4), 726-755.

\section{Publisher's Note}

Springer Nature remains neutral with regard to jurisdictional claims in published maps and institutional affiliations.

\section{Submit your manuscript to a SpringerOpen ${ }^{\circ}$ journal and benefit from:}

- Convenient online submission

- Rigorous peer review

- Open access: articles freely available online

High visibility within the field

Retaining the copyright to your article

Submit your next manuscript at $\boldsymbol{\nabla}$ springeropen.com 